\title{
Tumor analysis: freeze-thawing cycle of triple-negative breast cancer cells alters tumor CD24/CD44 profiles and the percentage of tumor-infiltrating immune cells
}

\author{
Matthieu Le Gallo ${ }^{1,2}$, Thibault de la Motte Rouge ${ }^{1,2}$, Amanda Poissonnier ${ }^{1,2,4}$, Vincent Lavoué ${ }^{1,2,3}$, Patrick Tas ${ }^{1,2,3}$, \\ Jean Leveque ${ }^{1,2,3}$, Florence Godey ${ }^{1,2}$ and Patrick Legembre ${ }^{1,2^{*}}$
}

\begin{abstract}
Objective: The use of novel methods to characterize living tumor cells relies on well-conceived biobanks. Herein, we raised the question of whether the composition of fresh and freeze/thawed dissociated tumor samples is comparable in terms of quantitative and qualitative profiling.

Results: Breast cancer is a heterogeneous disease, encompassing luminal A and B, basal/triple-negative breast cancer (TNBC), and ERBB2-like tumors. We examined living cells dissociated from TNBC and found that a classical freeze/thaw protocol leads to a marked reduction in the number of $\mathrm{CD} 45^{-} \mathrm{CD} 44^{\mathrm{Low}} \mathrm{CD} 24^{\mathrm{Low}}$ tumor cells. This, in turn, changed the percentage of tumor cells with certain CD44/CD24 expression patterns and changed the percentage of tumor-infiltrating immune cells. These cryopreservation-driven alterations in cellular phenotype make it impossible to compare fresh and frozen samples from the same patient directly. Moreover, the freeze/thaw process changed the transcriptomic signatures of triple-negative cancer stem cells in such a manner that hierarchical clustering no longer ranked them according to expected inter-individual differences. Overall, this study suggests that all analyses of living tumor cells should be conducted only using freshly dissociated tumors if we are to generate a robust scoring system for prognostic/predictive markers.
\end{abstract}

Keywords: Triple negative breast cancer, Immune infiltrate, Living biobank, Frozen

\section{Introduction}

Personalized medicine necessitates identification of biomarkers that are accurate, sensitive, and disease-specific. This is particularly true for cancer, which is a disease characterized by marked tumor heterogeneity. Although thousands of biomarkers have been described, few have translated successfully to the clinic. Biomarkers are crucial not only for tumor diagnosis and prognosis, but also for better stratification of patients, which reduces

\footnotetext{
*Correspondence: patrick.legembre@inserm.fr

${ }^{1}$ COSS (Chemistry Oncogenesis Stress Signaling)-UMR 1242, Inserm, Univ Rennes, CLCC Eugène Marquis, Rue Bataille Flandres Dunkerque, 35042 Rennes, France

Full list of author information is available at the end of the article
}

concerns related to over-treatment of indolent cancers and under-treatment of aggressive cancers.

Among women, breast cancer is the most common cause of cancer, and the second leading cause of cancer death after lung cancer $[1,2]$. Triple-negative breast cancer (TNBC) represents $15-20 \%$ of all breast cancer cases. It comprises a heterogeneous tumor subset that lacks expression of estrogen and progesterone receptors and does not overexpress HER2. As a group, TNBCs are aggressive and prognoses and clinical outcomes are poor [1]. The low percentage of tumor-infiltrating lymphocytes (TILs) [3] and accumulation of cancer stem cells (CSCs) [4] mean that TNBCs often show drug resistance, recurrence, and metastasis $[5,6]$. Therefore, exhaustive characterization of tumor-infiltrating immune cells and 
tumor cell heterogeneity is crucial if we are to identify new prognostic and predictive biomarkers and therapeutic targets.

Most, if not all, genomic and proteomic studies are performed using flash-frozen tumor tissues; hopefully, such tissues will yield transcriptomic and/or protein signatures that can be used to develop a personalized medicine approach. However, the complexity and heterogeneity of TNBC tumors mean that clinicians have yet to achieve this goal. We hypothesized that the use of novel methods to exhaustively characterize dissociated and living tumor cells may move us a step closer. For instance, multiparameter flow cytometry (i.e., cyTOF, single cell sequencing) can reveal detailed signatures that are unique to cells inside a tumor (e.g., immune, stromal, and tumor cells) and, by so-doing, identify new markers associated with relapse, and/or targets for a new generation of therapeutic drugs. Accordingly, laboratories will come to rely on well-conceived biobanks to develop dissociated cancer tissues.

\section{Main text}

\section{Methods and patients}

Patients

Patients $(n=15)$ were diagnosed and treated at the Centre Eugène Marquis between 2017 and 2018. None showed evidence of relapse at the time of diagnosis and none received chemotherapy, endocrine therapy, or radiation therapy prior to surgery. Treatment decisions and follow-up processes were based solely on international recommendations.

\section{Tumor samples}

Triple-negative breast tumors were collected by a pathologist after resection by a surgeon and immediately placed in RPMI medium. The dissociation process initiated within $2 \mathrm{~h}$ after surgical resection. Tumors were dissociated using the tumor dissociation kit (Human) (Miltenyi Biotec $\mathrm{GmbH}$ ), which is optimized to deliver a high yield of tumor cells and TILs while preserving important cell surface epitopes. TNBC pieces were weighed and cut into small pieces $\left(<2 \mathrm{~mm}^{3}\right)$, which were then treated with dissociation kit (Human) in a gentleMACS Dissociator, according to the manufacturer's recommendations. Briefly, tumors were mechanically dissociated in the gentleMACS dissociator for $36 \mathrm{~s}$ and then incubated at $37^{\circ} \mathrm{C}$ for 30 min under continuous rotation. Next, a cycle of mechanical-chemical-mechanical dissociation was performed and dissociated cells were resuspended in RPMI. Macroscopic pieces were removed using a Corning ${ }^{\circledR}$ cell strainer $(70 \mu \mathrm{m})$. Tumor cells were then washed twice in RPMI (20 ml) and counted using a hemocytometer.

\section{Flow cytometry}

Tumor cells (50,000 cells) were suspended in PBS supplemented with 2\% BSA, 2\% FCS, and FcR block (Miltenyi Biotec $\mathrm{GmbH}$ ) at $4{ }^{\circ} \mathrm{C}$ for $20 \mathrm{~min}$. Cells were then stained for $30 \mathrm{~min}$ at $4{ }^{\circ} \mathrm{C}$ with anti-CD24 PE (clone ML5, BD Biosciences), anti-CD44 APC (clone G44-26, BD Biosciences), and anti-CD45 PE-Vio770 (clone 5B1, Miltenyi Biotec $\mathrm{GmbH}$ ) antibodies. Isotypic antibodies were used as a control for each fluorochrome (obtained from the same manufacturers). Cells were then washed twice in PBS supplemented with 2\% BSA and 2\% FCS and resuspended in PBS. To assess cell viability, cells were incubated with 7-AAD (BD Biosciences) for $10 \mathrm{~min}$ prior to cytometry analysis. Data were acquired using a Novocyte cytometer (ACEA Biosciences) and analyzed using FlowJo or Novoexpress software.

\section{Cryopreservation and storage}

The freezing process was carried out using standardized freezing procedures, following the guidelines issued by the "Haute Autorite de Santé", the government agency regulating the French healthcare system, for human tissue and cell samples biobanking. Freshly dissociated tumor cells were frozen in $1 \mathrm{ml}$ of human serum albumin (HSA) Vialebex ${ }^{\circledR}$ (LFB BIOMEDICAMENTS, Les Ullis, France) supplemented with 10\% DMSO (Sigma Aldrich). Each vial contained $2-5 \times 10^{6}$ cells (depending on the tumor dissociation yield). Briefly, freshly dissociated cell pellets were resuspended in $500 \mu \mathrm{l}$ of pre-cooled HSA. Then, $500 \mu \mathrm{l}$ of pre-cooled HSA containing $20 \%$ DMSO solution was added drop by drop to the cell suspension. The suspension was then homogenized and transferred to a cryotube. To ensure a standardized and controlled rate of freezing $\left(-1{ }^{\circ} \mathrm{C} / \mathrm{min}\right)$, cryotubes were first placed in a CoolCell ${ }^{\circledR}$ LX Cell Freezing Container (BioCision) at $-80^{\circ} \mathrm{C}$. After $24 \mathrm{~h}$, cells were transferred to a freezer set at $-150{ }^{\circ} \mathrm{C}$. All freezers were monitored; no critical temperature variations were recorded during storage.

For thawing, cells were placed in a water bath at $37{ }^{\circ} \mathrm{C}$ and then transferred to RPMI ( $40 \mathrm{ml})$ at RT to allow complete thawing. After a second wash in $20 \mathrm{ml}$ of RPMI, the cells were counted using a hemocytometer. Cell viability was assessed using Trypan Blue.

\section{Generation of mammospheres}

Matched freshly dissociated and thawed tumor cells from the same patient were treated in the same way. Cells $\left(1.5 \times 10^{6}\right)$ were seeded in $2 \mathrm{ml}$ of Mammocult medium (StemCell Technologies) supplemented with heparin $(4 \mu \mathrm{g} / \mathrm{ml}$; Stem Cell Technologies), hydrocortisone $(480 \mathrm{ng} / \mathrm{ml}$; Stem Cell Technologies), penicillin (100 units/ml), and streptomycin $(100 \mu \mathrm{g} / \mathrm{ml})$ (Gibco) in 
ultra-low binding 6-well plates (Corning). After 15 days at $37{ }^{\circ} \mathrm{C} / 5 \% \mathrm{CO}_{2}$, mammospheres were collected and passed through a cell strainer $(40 \mu \mathrm{m})$ to separate suspended cells from mammospheres. Next, mammospheres were dissociated with trypsin/EDTA $(0.05 \%$ trypsin; Gibco) for $5 \mathrm{~min}$. Dissociated cells were washed twice in PBS and stained as described above. RNA extracted from mammospheres using the NucleoSpin RNA XS extraction kit (Macherey-Nagel), according to the manufacturer's recommendations.

\section{Microarray analysis}

RNA quality was assessed using an RNA6000 nano chip (Agilent). For each condition (fresh or freeze/thawed), 9 ng of RNA was reverse transcribed using the Ovation PicoSL WTA System V2 (Nugen, Leek, The Netherlands). Fragmented cDNAs were hybridized to GeneChip Human Gene 2.0 ST microarrays (Affymetrix), which were scanned by a GeneChip Scanner 3000 7G (Affymetrix). Raw data and quality-control metrics were generated using Expression Console software (Affymetrix). Probes were mapped using Brainarray V23 CDF files (http://brainarray.mbni.med.umich.edu/) and normalized by robust multi-array averaging with $\mathrm{R}$ software. Statistical analyses were performed using the limma $R$ package; genes showing a twofold change in expression and a $P$ value of 0.05 were considered significant. Gene Ontology terms enrichment analyses were performed using the ToppGene Suite (Chen J, Bardes EE, Aronow BJ, Jegga AG 2009. ToppGene Suite for gene list enrichment analysis and candidate gene prioritization. Nucleic Acids Research https://doi.org/10.1093/nar/gkp427). Hierarchical clustering was performed using Morpheus Matrix visualization and analysis software (https://softw are.broadinstitute.org/morpheus/).

\section{Accession numbers}

Raw and normalized data have been deposited to the GEO database accession ID GSE114359.

\section{Results}

We raised the question of whether the composition of fresh and freeze/thawed samples from the same patients was sufficiently similar in terms of quantitative and qualitative profiling and asked whether both could be used to investigate TILs (CD45-positive cells) and the phenotype $\left(\mathrm{CD} 45^{\text {neg }} \mathrm{CD} 24^{\mathrm{Low}} \mathrm{CD} 44^{\text {High }}\right)$ of CSCs. To address this, we used multiparameter flow cytometry to compare the phenotypes of 15 freshly dissociated TNBCs and their matched cryopreserved counterparts. Briefly, to minimize mortality due to sample processing time, the pathologist collected samples in RPMI medium and the dissociation process was started within a maximum of 120 min after surgical resection. Fresh TNBCs were dissociated using the Miltenyi Tumor dissociation kit (Human); 0.8 million cells were analyzed. In parallel, we cultured $1.5 \times 10^{6}$ cells in serum-free medium in low-attachment plates to isolate spheroids, which are enriched in CSCs (see "Methods and patients" section). The remaining cells were frozen using a standardized procedure following the French "Haute Authorité de Santé" guidelines to biobanks and kept for 2 weeks in a freezer at $-150{ }^{\circ} \mathrm{C}$. The cells were then thawed and analyzed immediately by flow cytometry; spheroids were also generated. Total RNA was isolated from fresh and thawed spheroids and the transcriptomic signatures compared (see Additional file 1: Figure S1).

Cell viability was assessed by 7 -AAD staining. The results showed that the freezing/thawing procedure for dissociated TNBC cells yielded $25.4 \%$ dead cells, with five dissociated tumor samples showing a drop in absolute numbers of $10 \%$ or less, and four tumors showing more than $50 \%$ dead cells (Fig. 1a) after thawing. The reasons for this were unknown since all samples were treated in a similar manner. Strikingly, most of the cells that died following the freezing/thawing process originated from the CD45- population (Fig. 1b), which in turn impacted the percentage of tumor-infiltrating leukocytes (i.e., CD45 + cells; Fig. 1b). Of note, the percentage of tumor cells with a CD $45^{-} \mathrm{CD} 24^{\text {Low }} \mathrm{CD} 44^{\text {Low }}$ phenotype fell markedly after thawing (Fig. 1c, d). Two hypotheses may explain these losses: either these cells are highly sensitive to freezing/thawing, or they are reprogrammed to exhibit a different CD24/CD44 phenotype. The percentage of dead cells observed in Fig. 1a and the short delay between thawing and immunophenotyping are not compatible with the latter hypothesis, strongly suggesting that $\mathrm{CD} 45^{-} \mathrm{CD} 24^{\mathrm{Low}} \mathrm{CD} 44^{\mathrm{Low}}$ cells do not tolerate the freeze/thaw process well. Loss of this population resulted mainly in artificial enrichment of the $\mathrm{CD} 24^{\mathrm{High}} \mathrm{CD} 44^{\mathrm{Low}}$ cell population and, albeit to a lesser extent, the $\mathrm{CD} 24^{\mathrm{Low}} \mathrm{CD} 44^{\mathrm{High}}$ and $\mathrm{CD} 24^{\mathrm{High}} \mathrm{CD} 44^{\text {High }}$ populations (Fig. 1d). Because the $\mathrm{CD} 24^{\mathrm{Low}} \mathrm{CD} 44^{\mathrm{High}}$ lineage was enriched after the freeze/thaw cycle, and this cell subset seems to correspond to stem/progenitor cancer cells [5, 6], we next wondered whether the transcriptomic signature of these enriched CSCs varied after the freezing/ thawing process. To compare the transcriptome of CSCs derived from fresh and frozen samples, we used stringent cell culture procedures to culture spheroid cells. Compared with the bulk of dissociated tumor cells, spheroids were enriched for $\mathrm{CD} 24^{\mathrm{Low}} \mathrm{CD} 44^{\mathrm{High}}$ cells (Fig. 2a). Next, we examined freshly dissociated TNBC cells from three different TNBC patients, along with the cells from the same patients frozen immediately after dissociation and cryopreserved for 15 days before thawing. Both sets of 


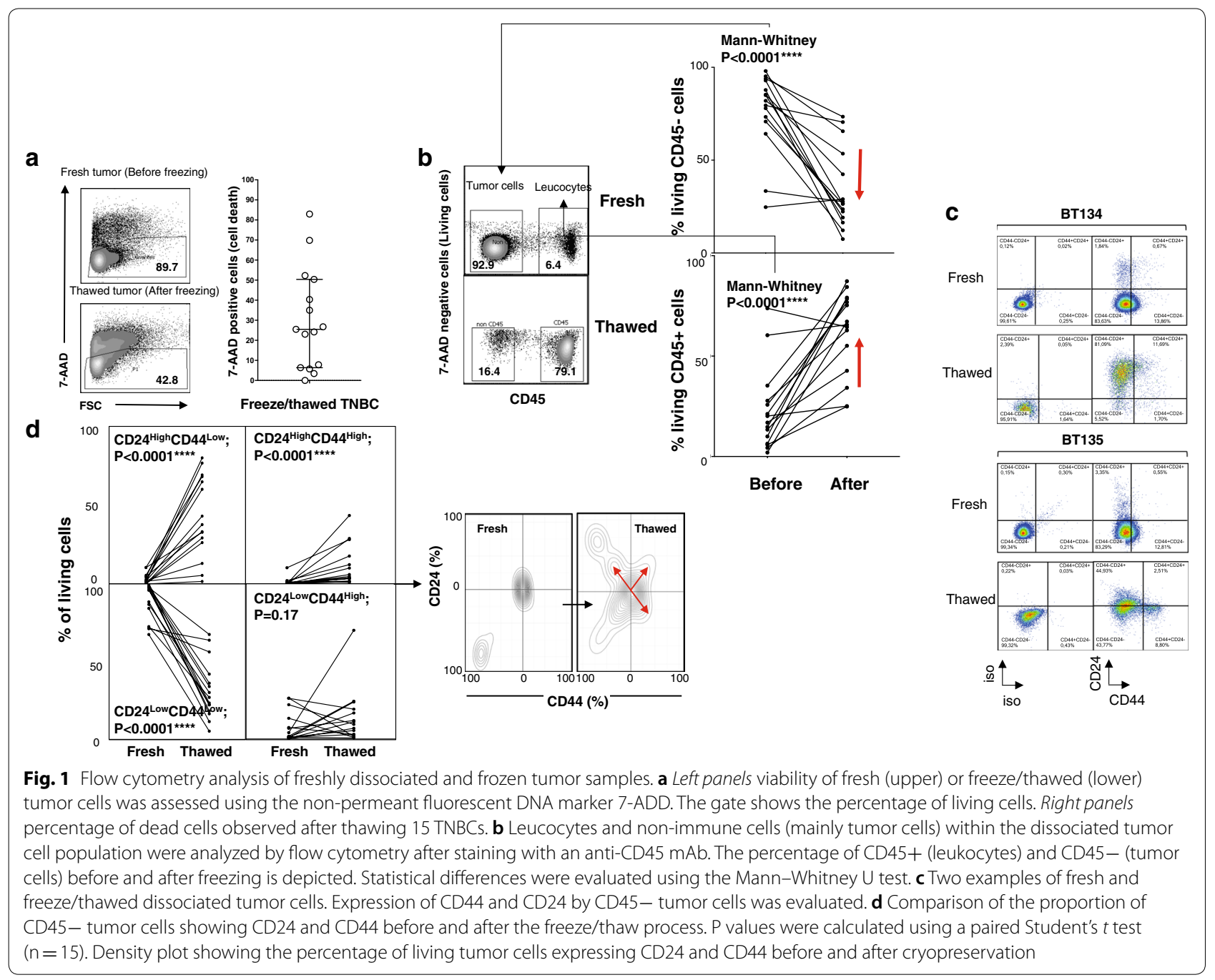

cells were cultured for 15 days in serum-free medium in low-adherence plates to select CSCs $\left(\mathrm{CD} 44^{\text {High }} \mathrm{CD} 24^{\text {Low }}\right)$ and the transcriptomic signatures were compared (Fig. 2b). Unexpectedly, unsupervised hierarchical clustering of these tumor cells ranked tumors according to whether they had been subjected to freeze/thaw treatment and not according to their inter-individual differences; this shows that freeze/thawing the cells had a deleterious effect in their transcriptomic signatures. Gene Ontology terms enrichment analysis revealed that the freeze/thaw process drove deregulation of 274 genes (-fold change $>2, \mathrm{P}<0.05$ ); most of these were associated to epithelial to mesenchymal transition (EMT), tissues morphogenesis and cell junction and adhesion (Fig. 2c). Of these, 224 genes (82\%) in freeze/thaw spheroids were significantly down-regulated when compared with those in fresh spheroids( Table 1). Because these genes play a role in organization of cell junctions and are lost during freeze/thaw of CSCs, we suggest that cryopreservation either spares breast cancer stem cells showing the most dedifferentiated mesenchymal profiles or favors EMT reprogramming (Fig. 2c and Additional file 2: Table S1).

\section{Discussion}

Although one study did examine the impact of cryopreservation on gametes and embryos, this study appears to be the first to examine phenotypic changes caused by freeze/thawing living cells isolated from cancer patients [7].

Although molecular oncology has opened new avenues to classifying human cancers from a molecular standpoint, a number of issues associated with heterogeneous genomic platforms limit their ability to identifying signatures capable of predicting biological 


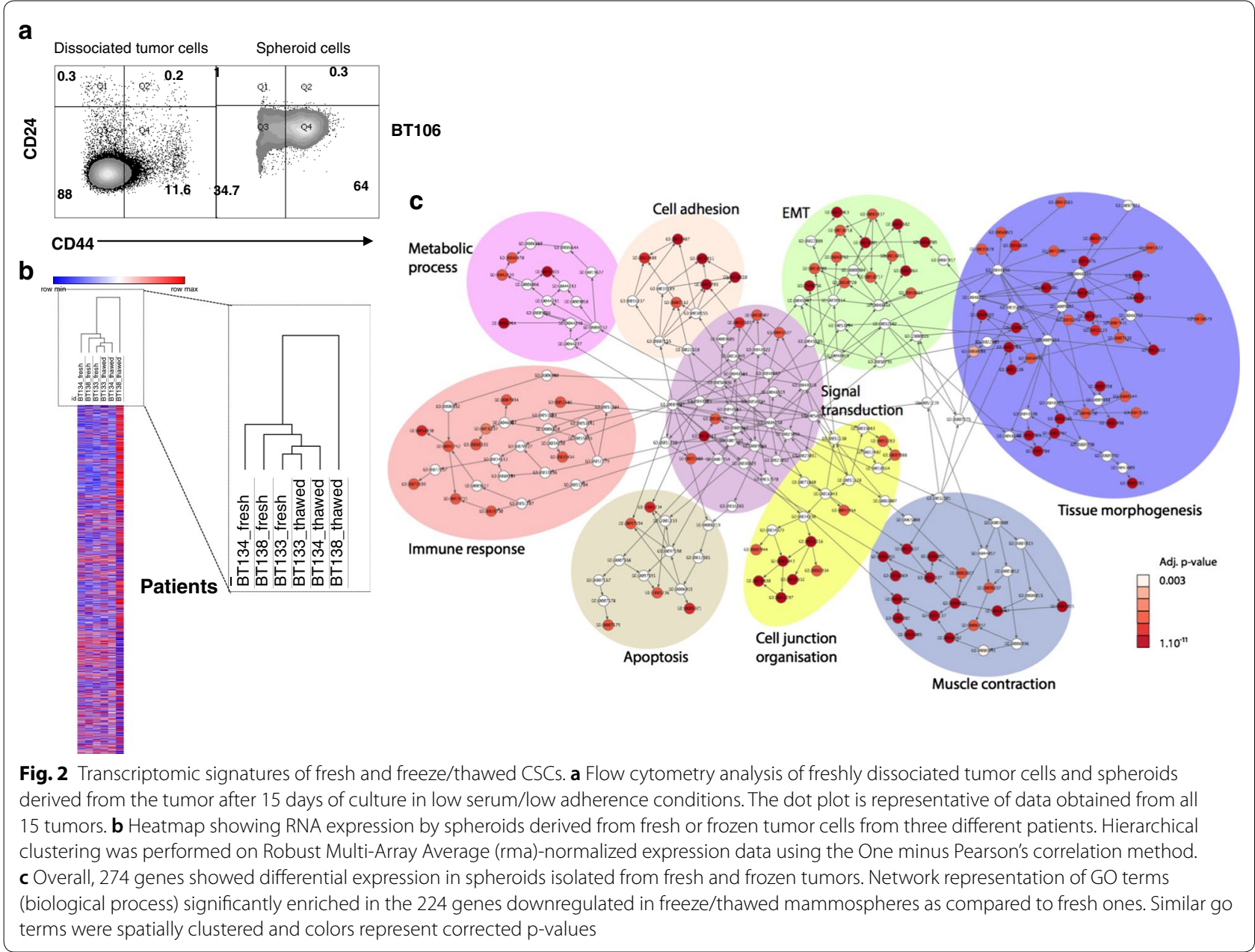

behavior and/or identifying new molecular targets for more effective and less toxic therapeutic interventions [8]. We identified a novel issue using data meta-analysis based on profiling of fresh and frozen tumor samples; our findings suggest that it will be difficult to identify robust signatures transposable to patients if freeze/ thawed dissociated cancer tissues are used.

We strongly discourage the use of frozen dissociated tumor sample for accurate cell population characterization, as thawing creates a disequilibrium in the proportion of immune and tumor cell subpopulations. In addition, because the transcriptomic signatures of mammospheres derived from frozen/thawed samples are not representative of those of initial CSCs, this study rules out their use for identification of new prognostic and/or therapeutic targets. We strongly suggest that future studies involving dissociated tumor cells should be conducted using fresh tumors only; in parallel, tumor biobanks should develop validate methods of freezing living cells isolated from resected tumors that preserves tumor heterogeneity. In this way, we may be able to generate robust scoring systems for prognostic, predictive, and therapeutic markers. Such a system is an unmet clinical need with respect to patients with TNBC.

\section{Limitations}

Although, the freeze-thaw shock seems mainly to affect immune cells, a more detailed analysis would be required to further investigate whether some minor immune subsets could be affected by this stress and thereby, could also alter the conclusions drawn from analyses performed using freeze/thaw living cells. 


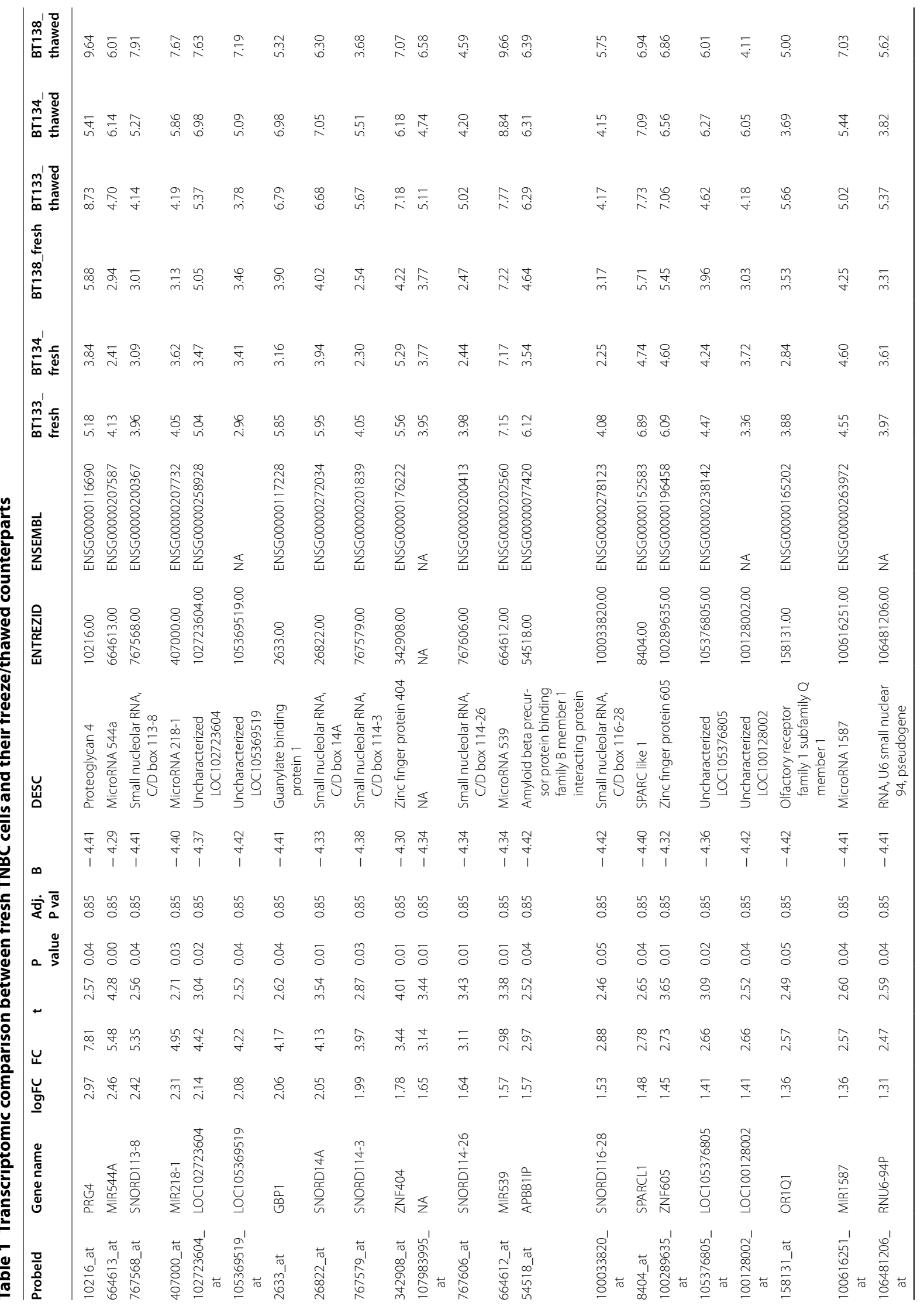

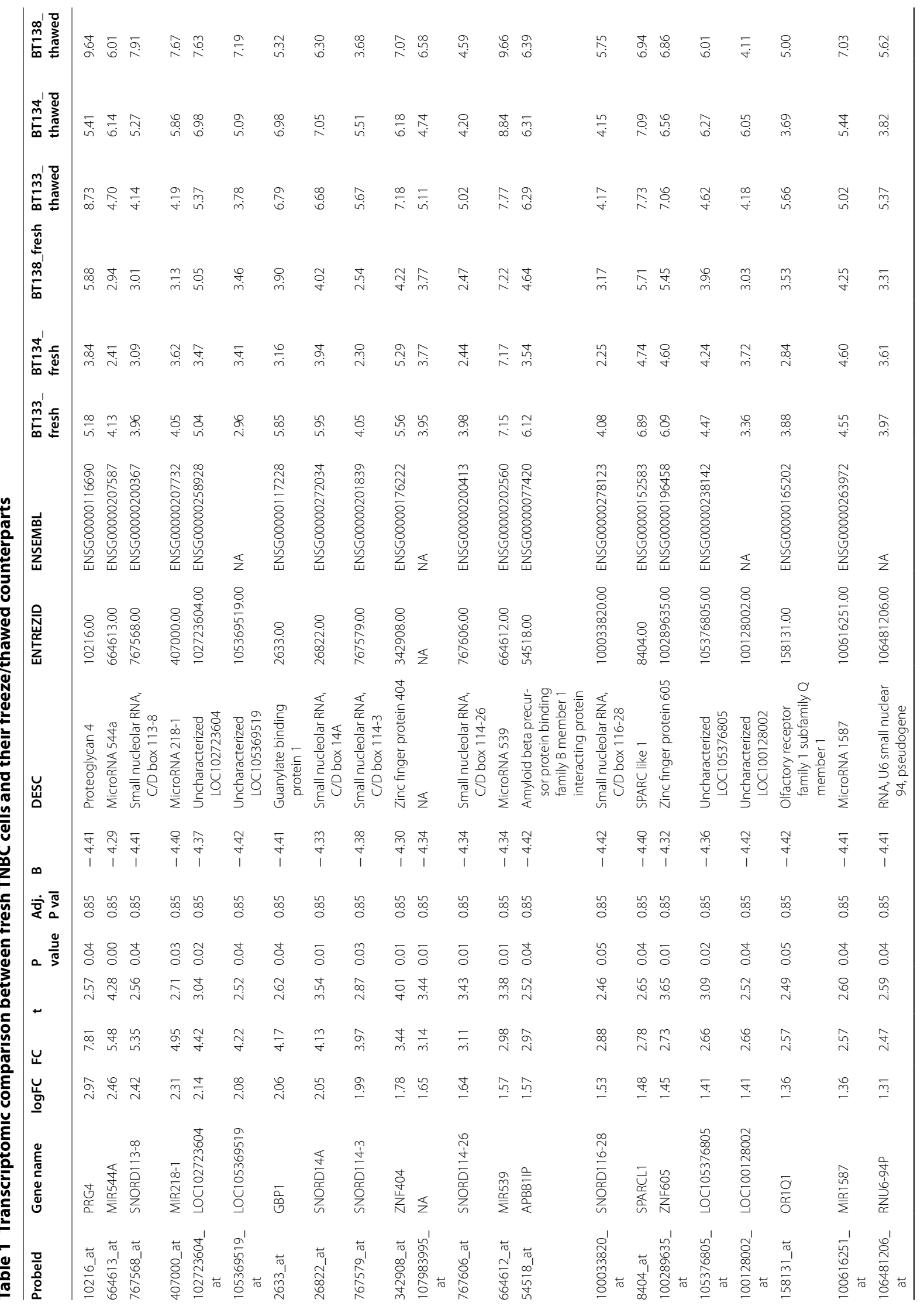

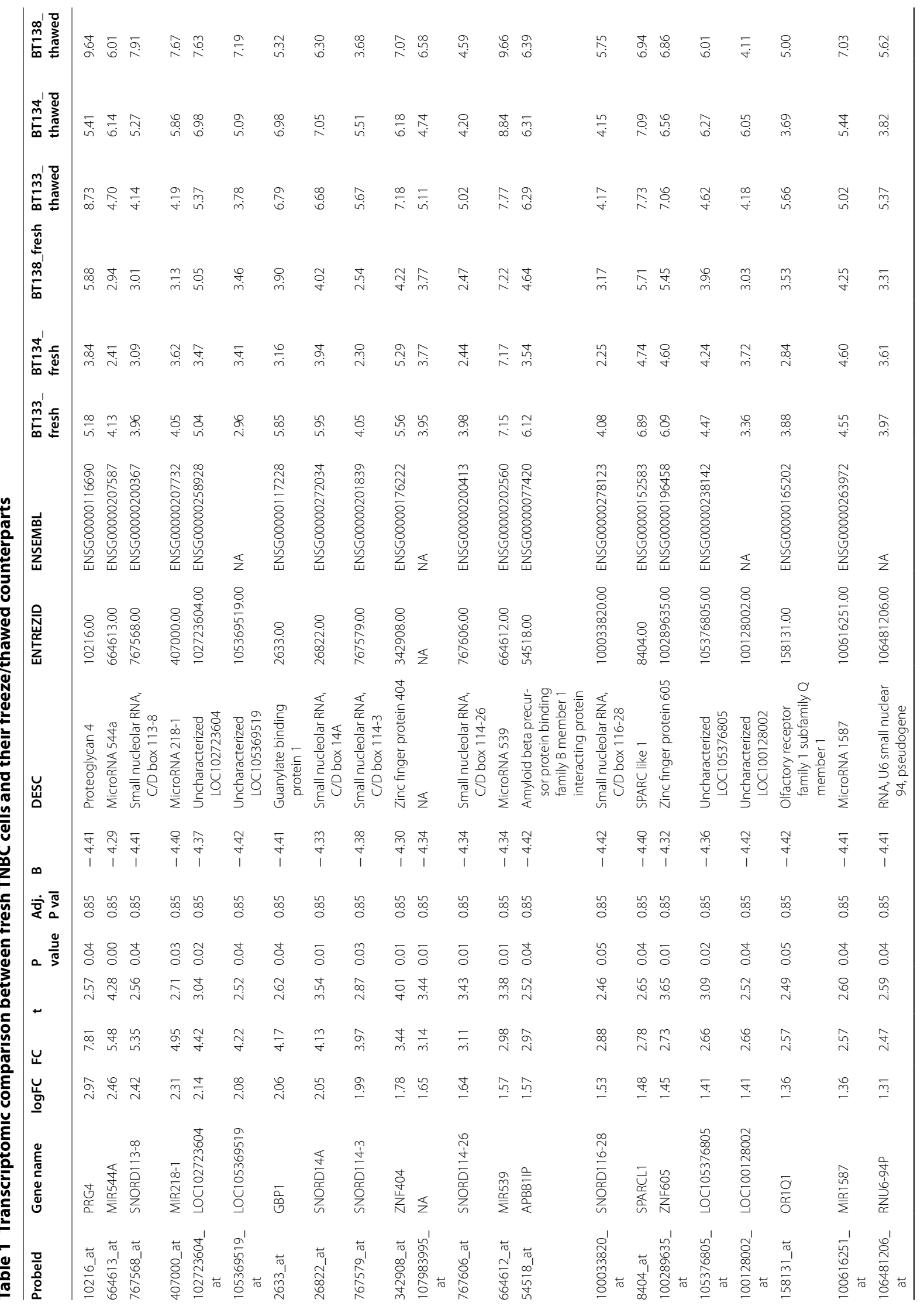

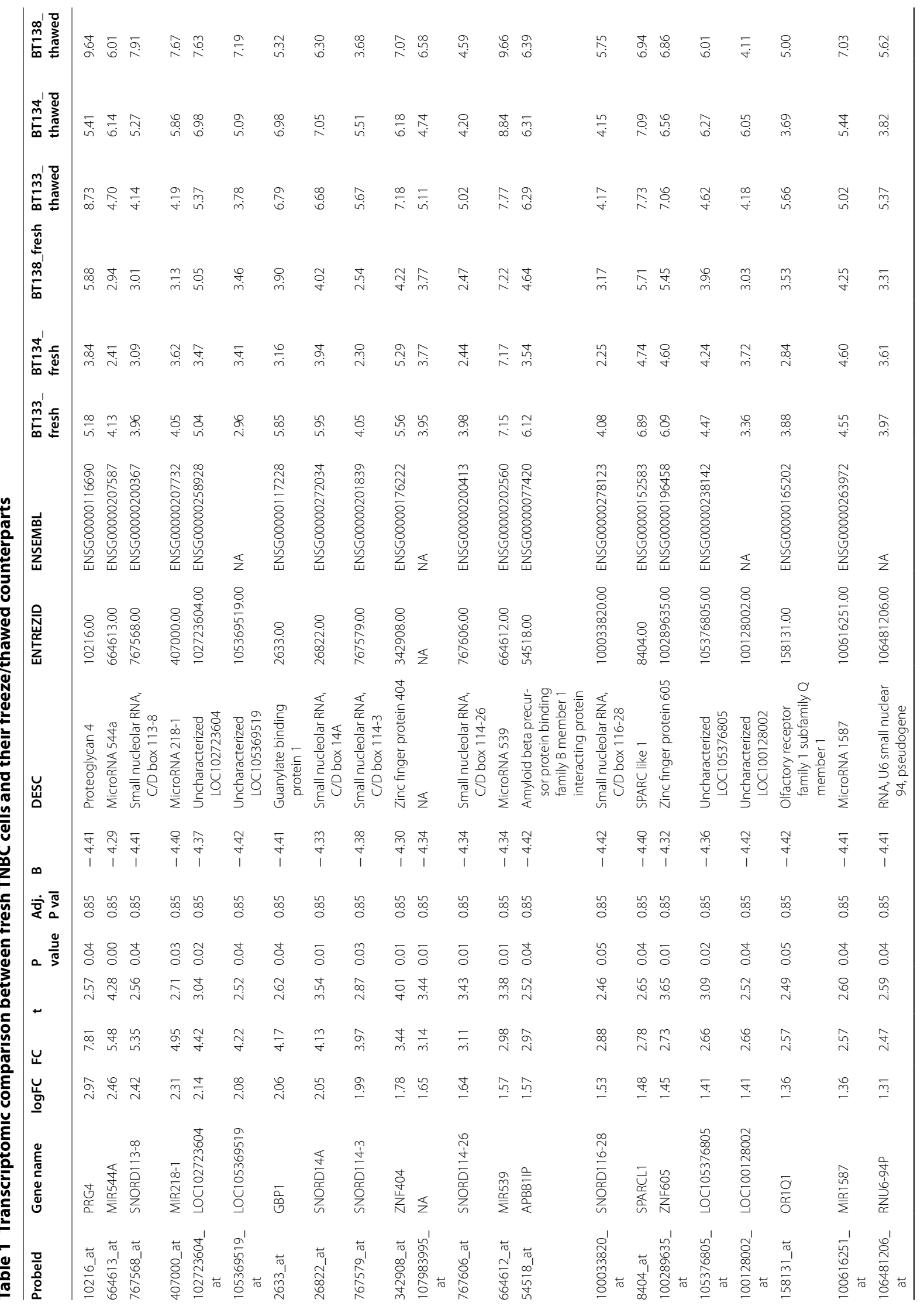

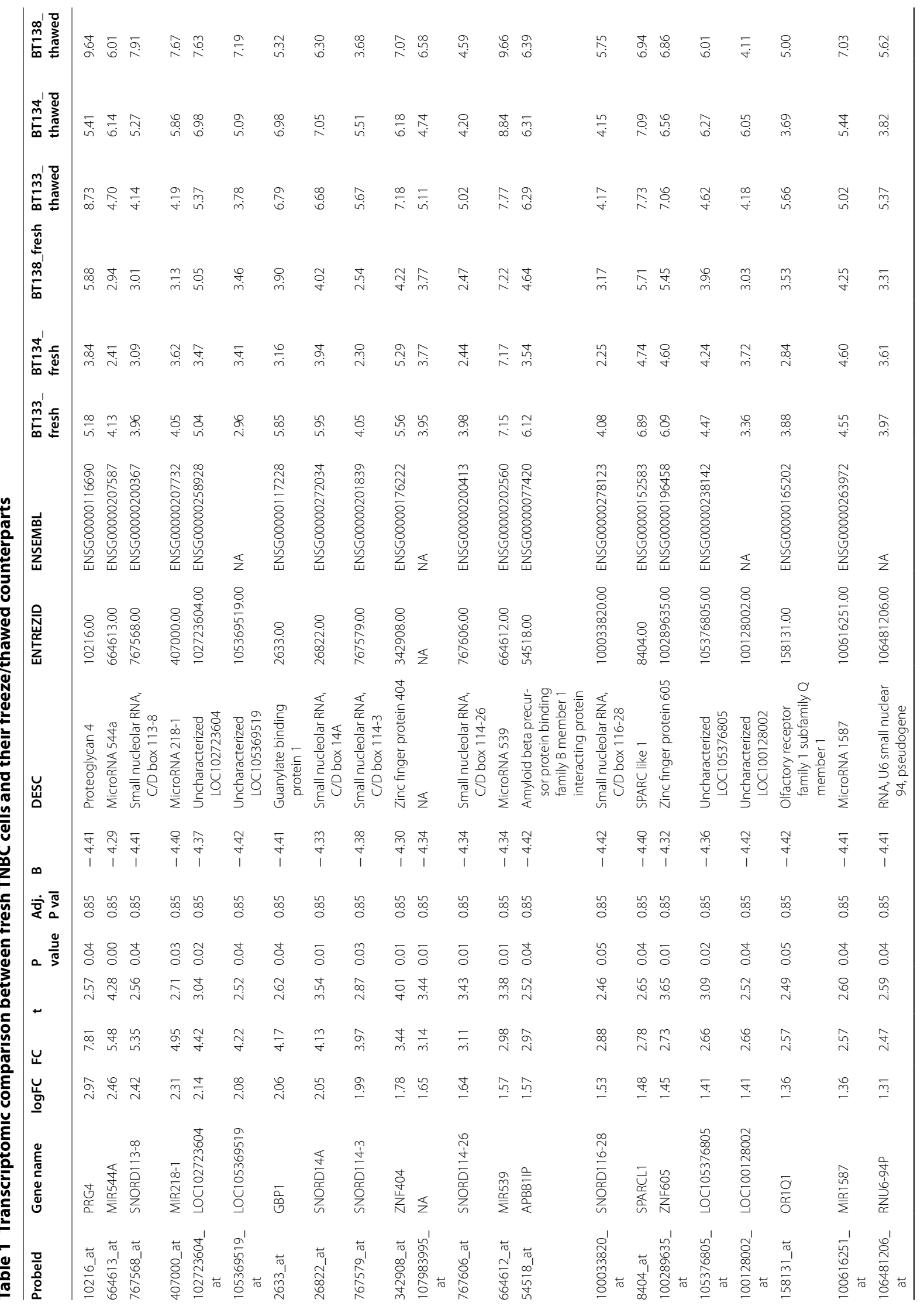

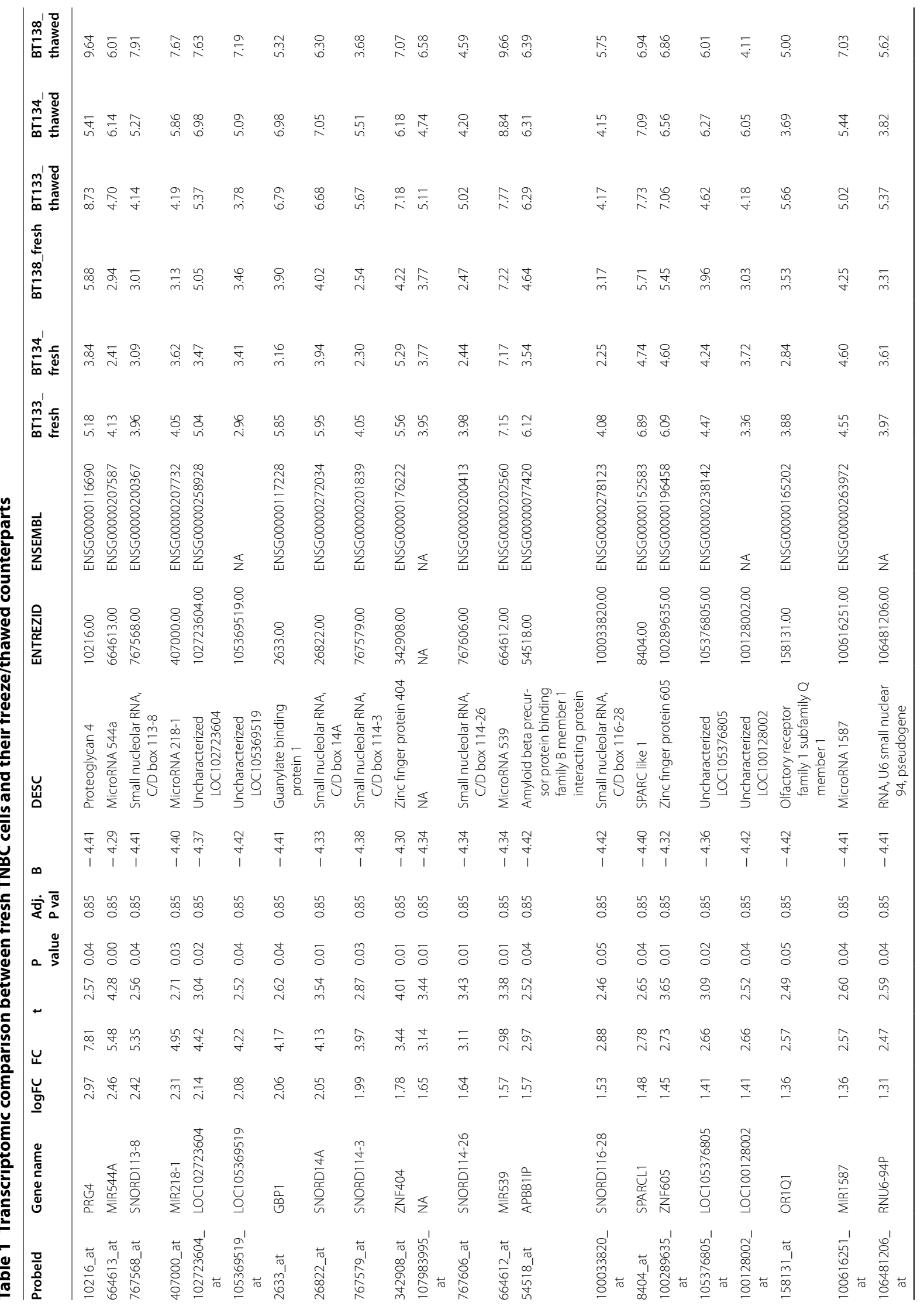

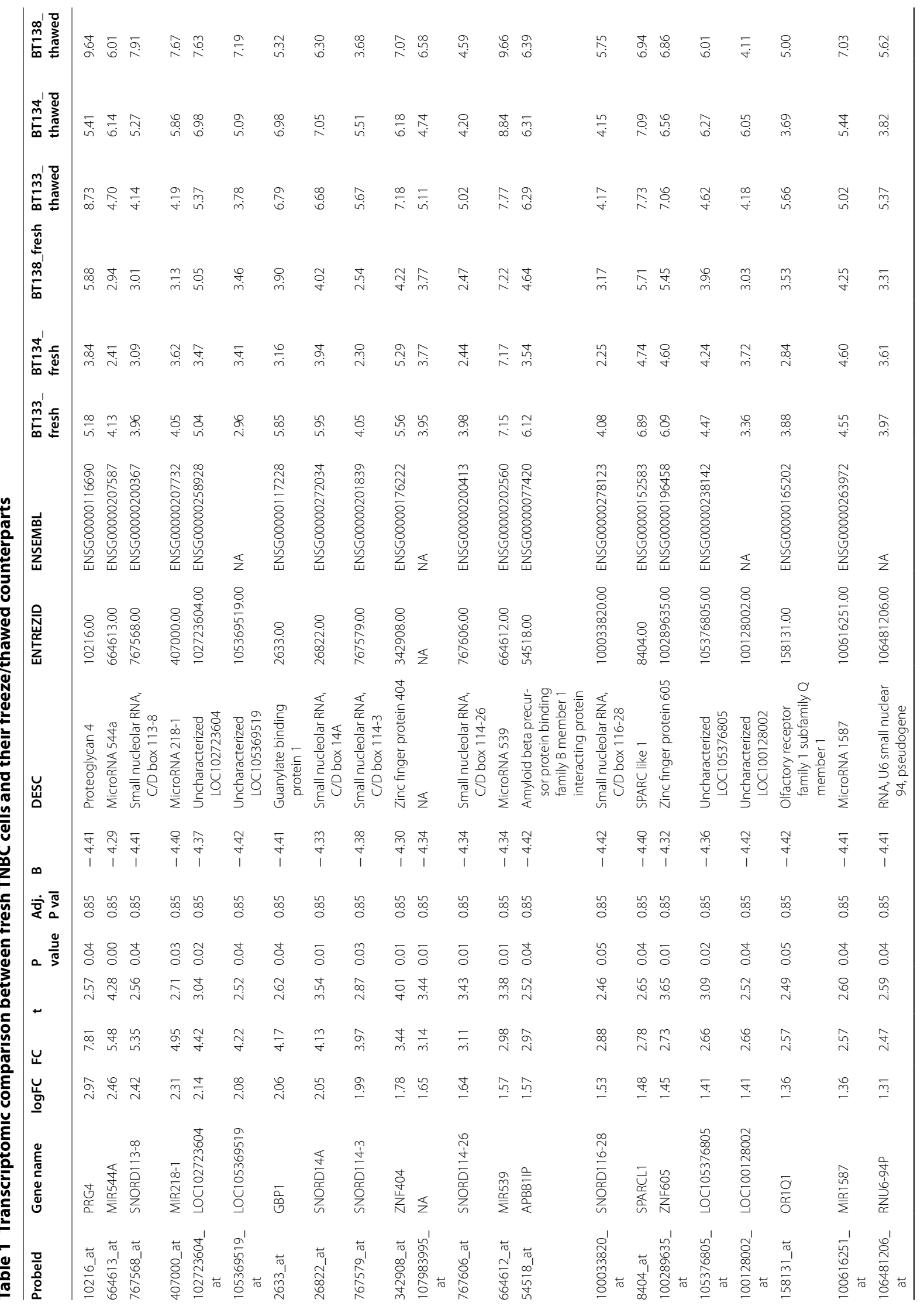

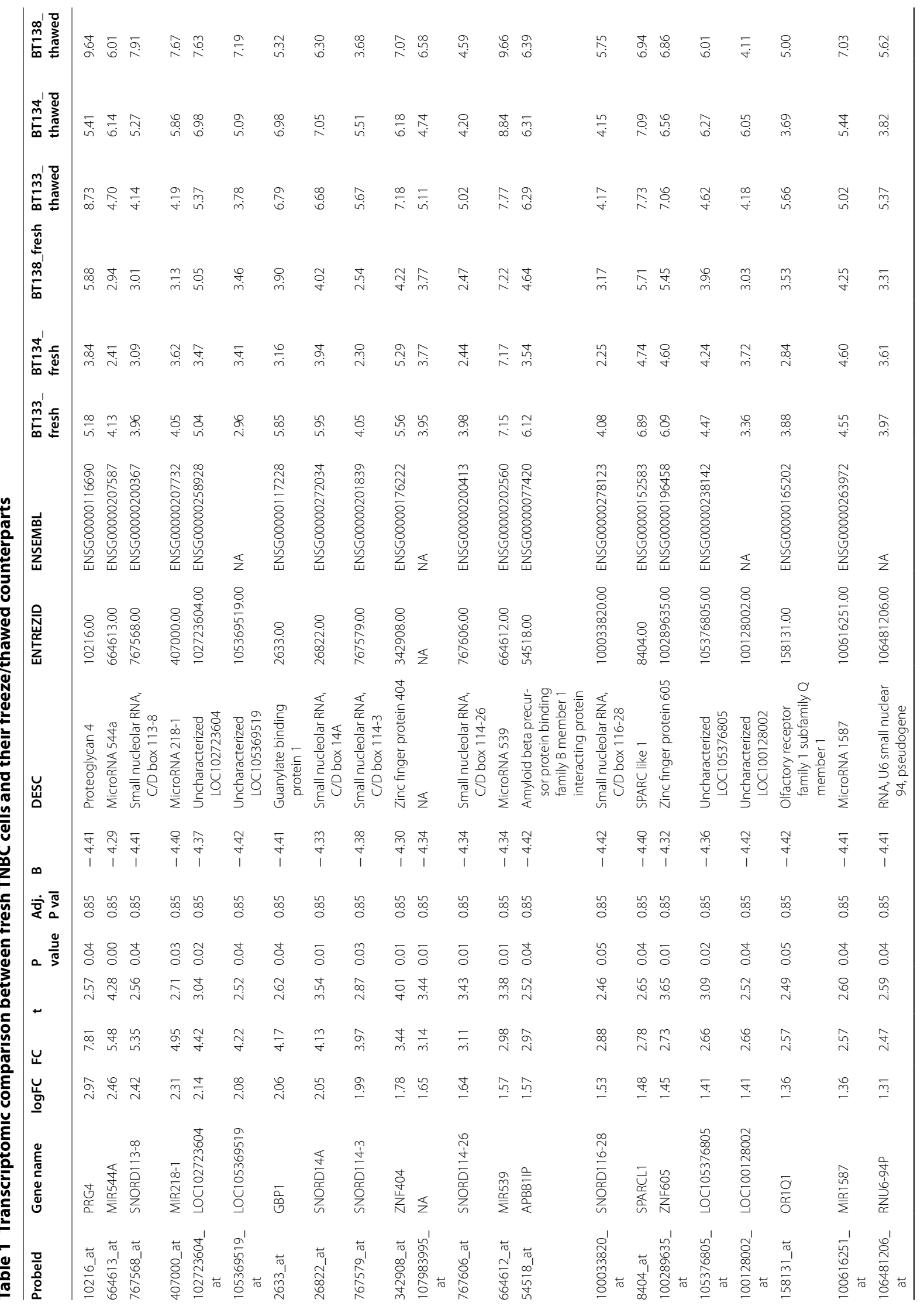




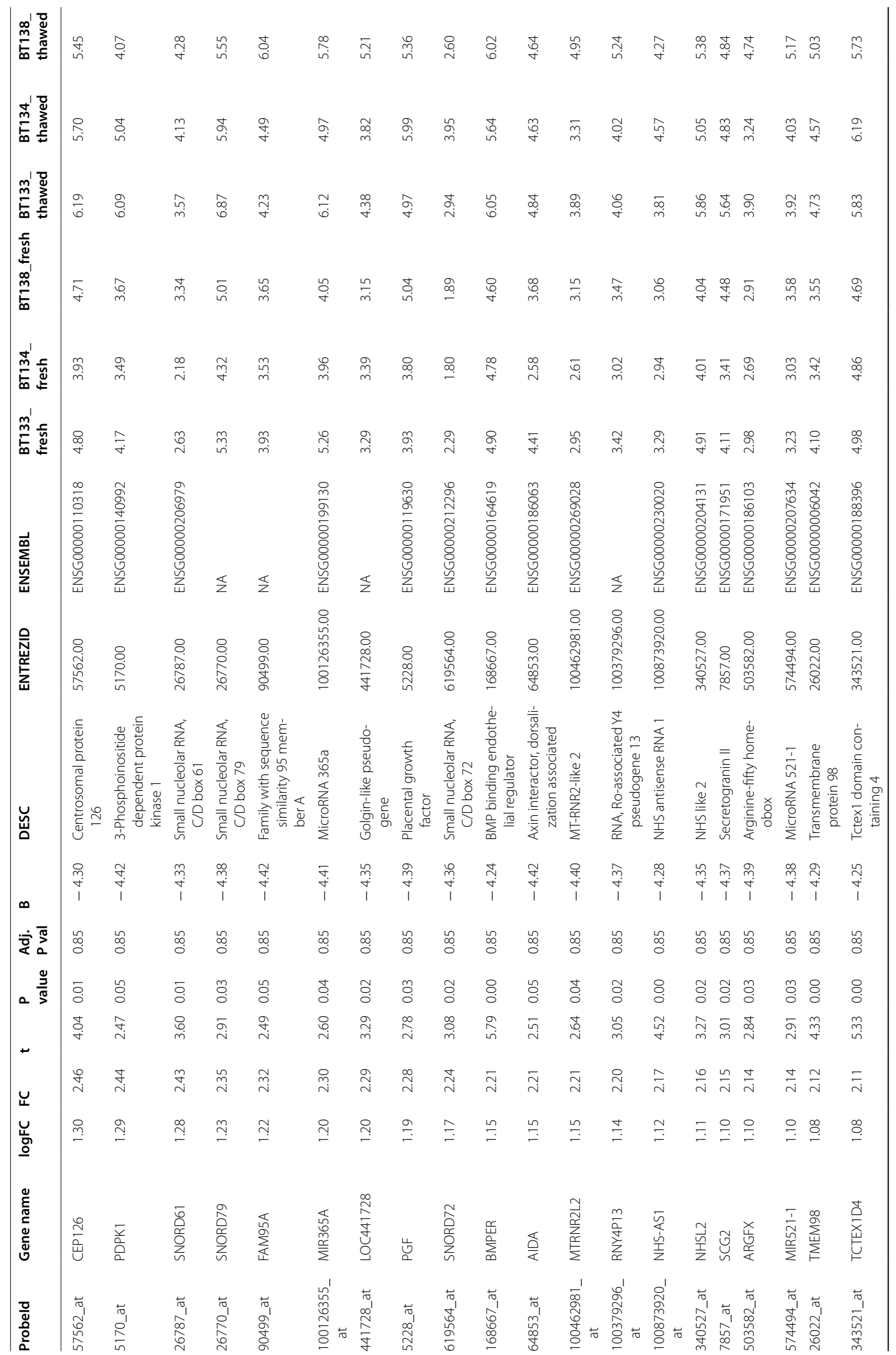


Le Gallo et al. BMC Res Notes (2018) 11:401

Page 8 of 20

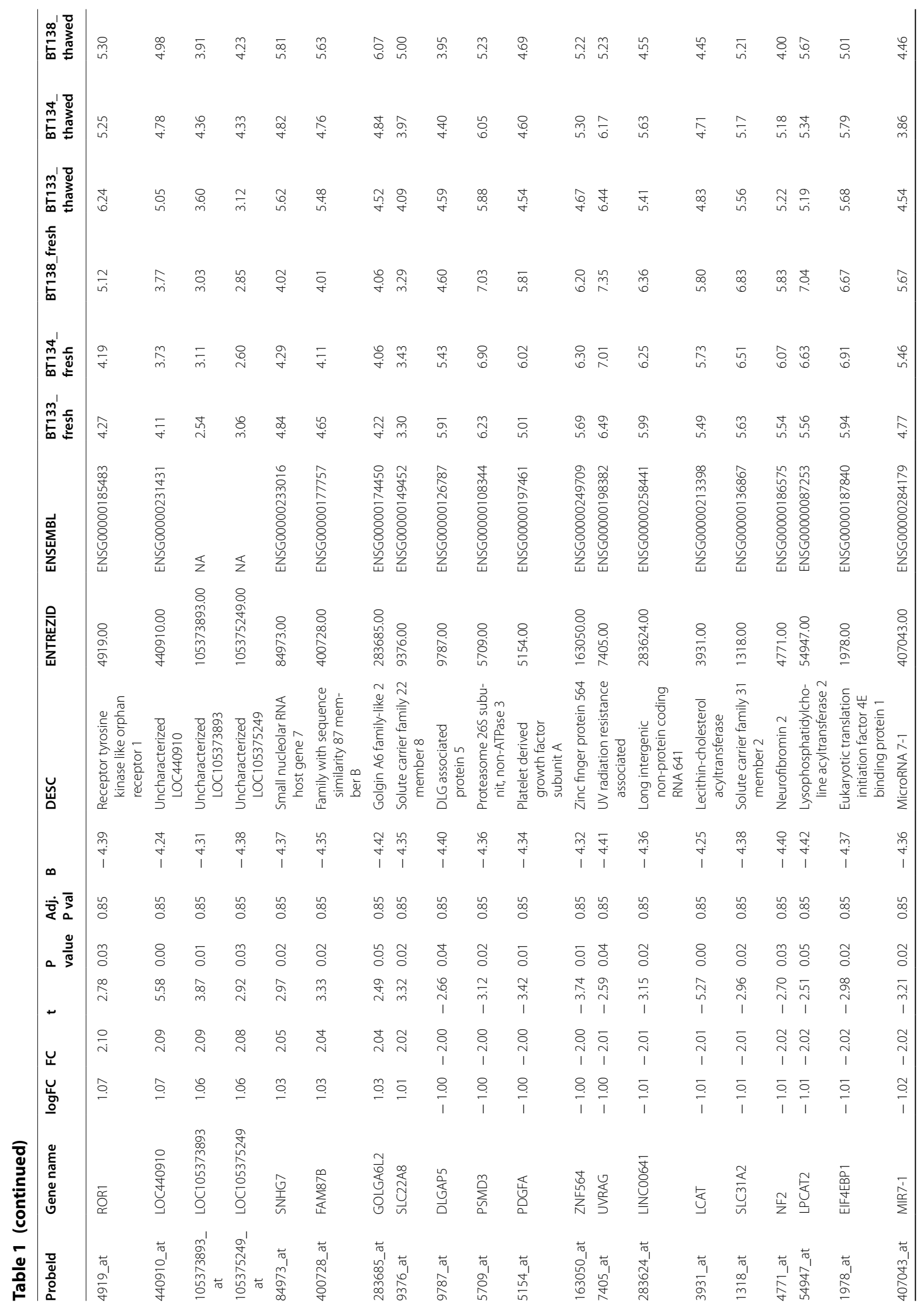




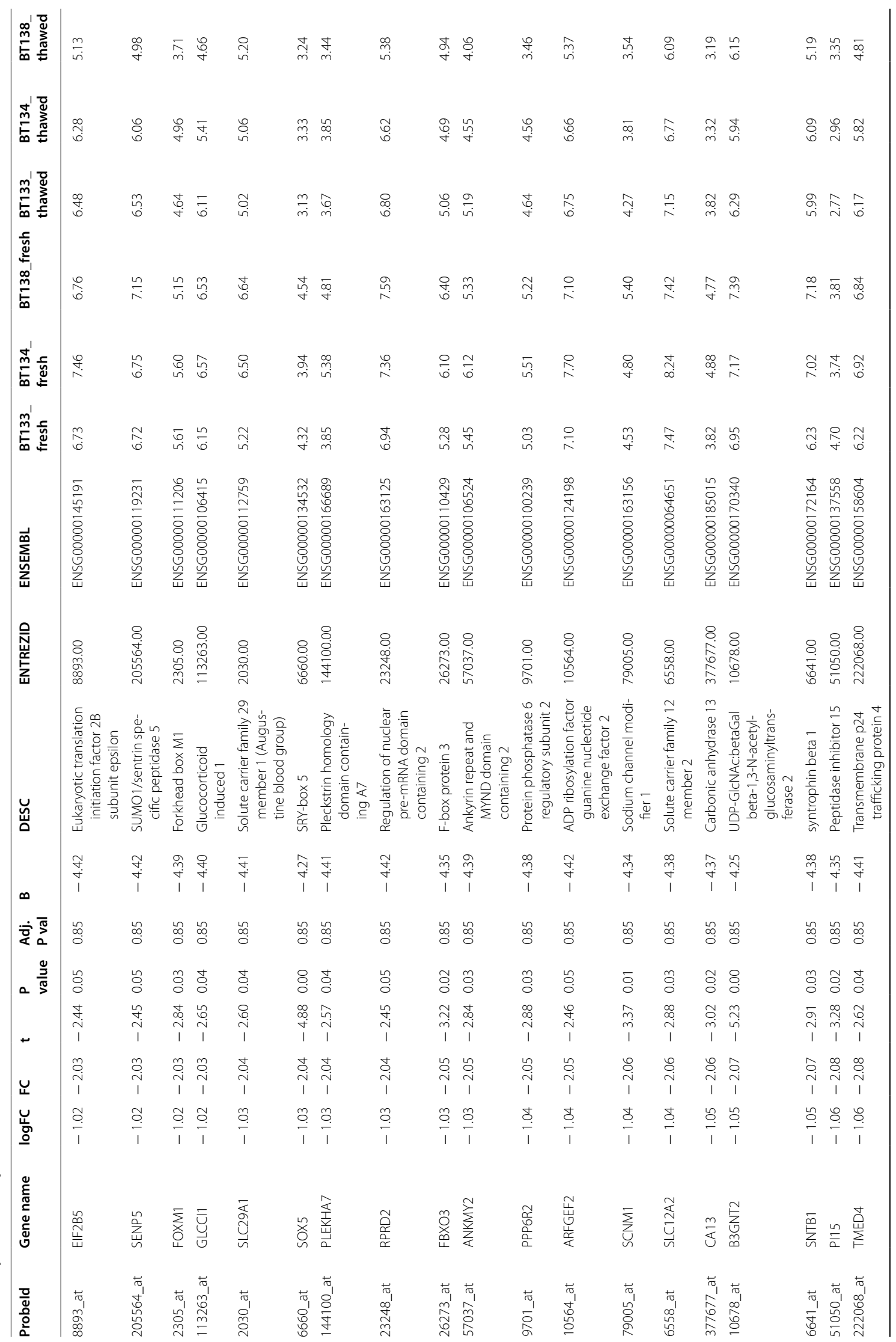




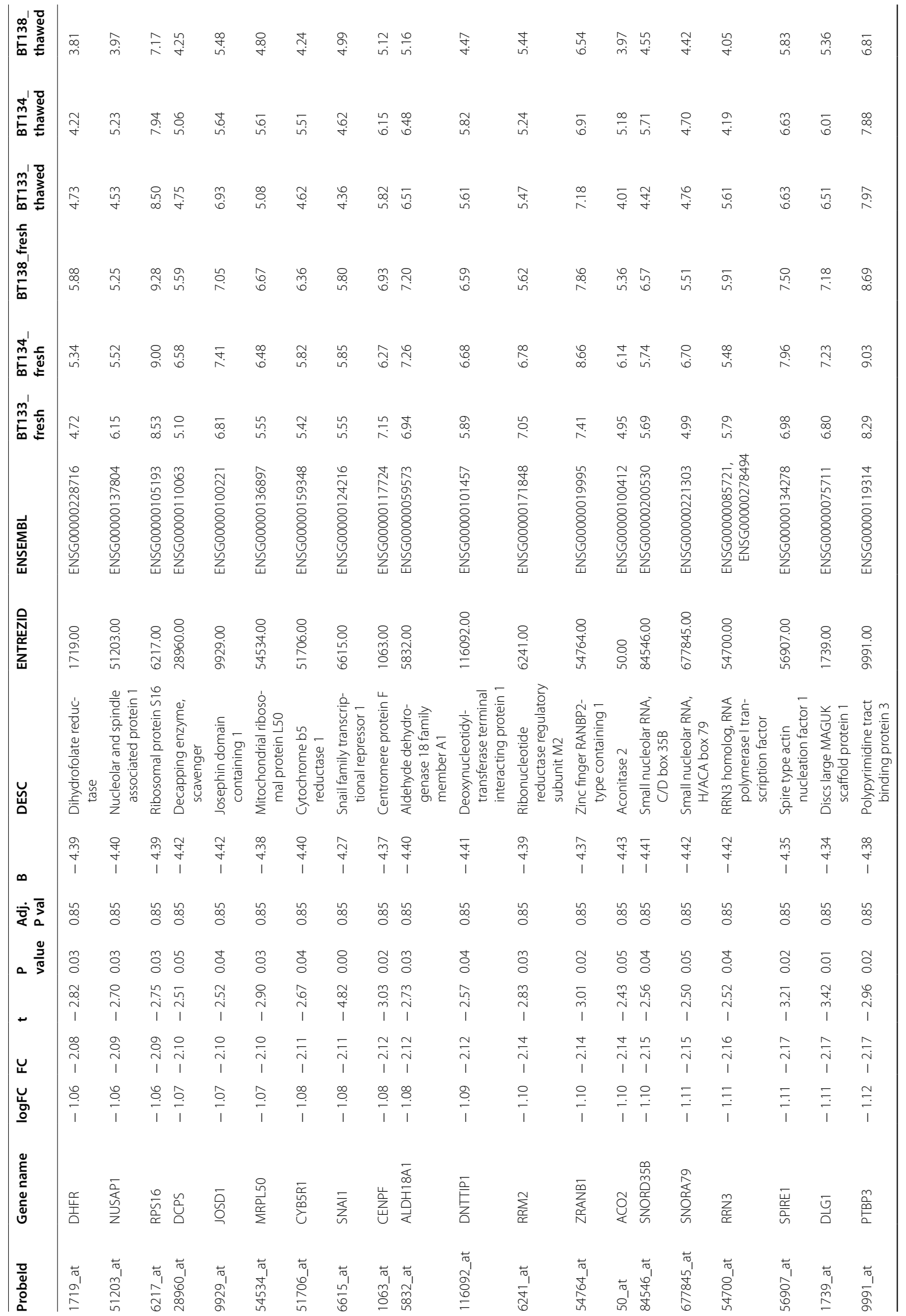




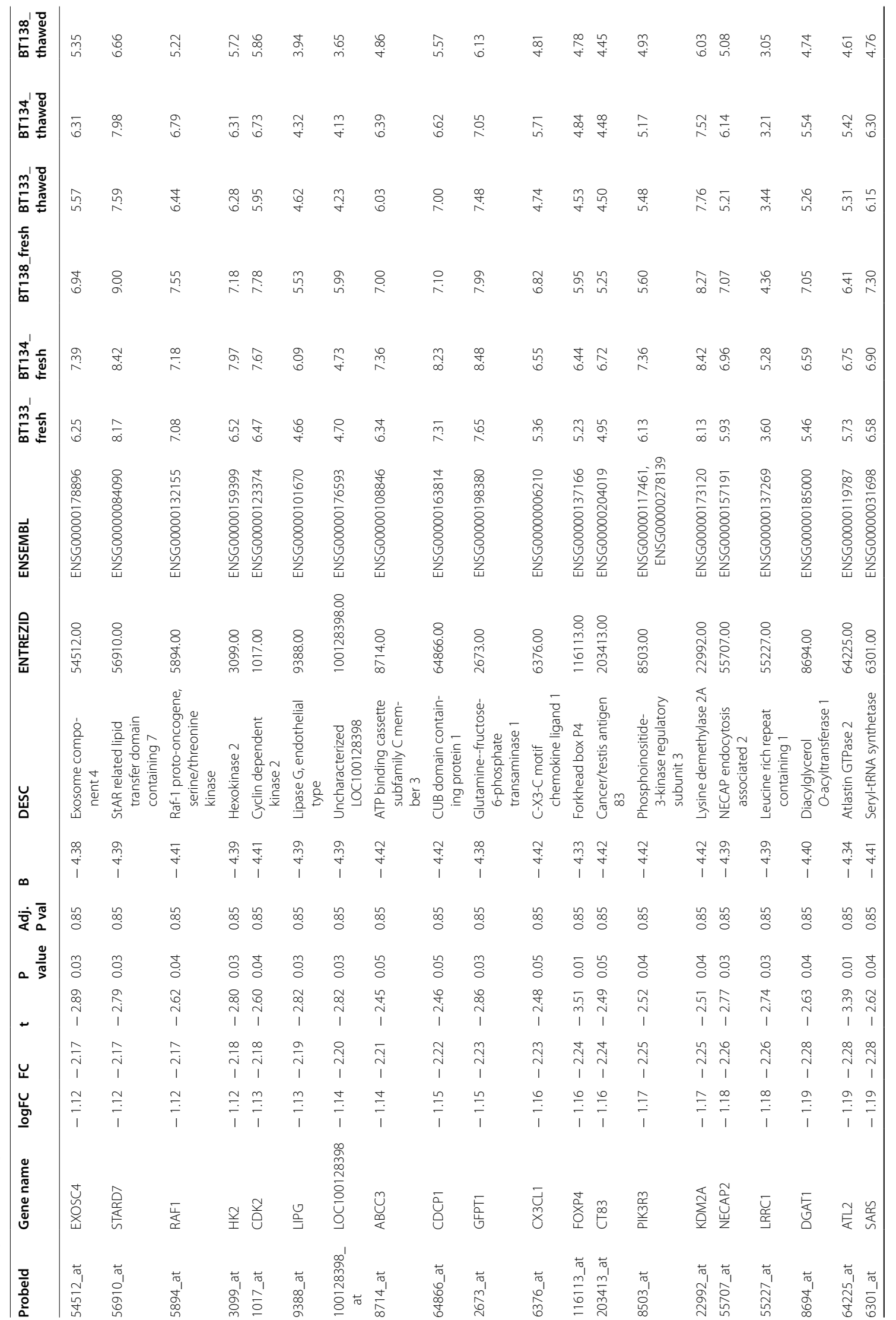




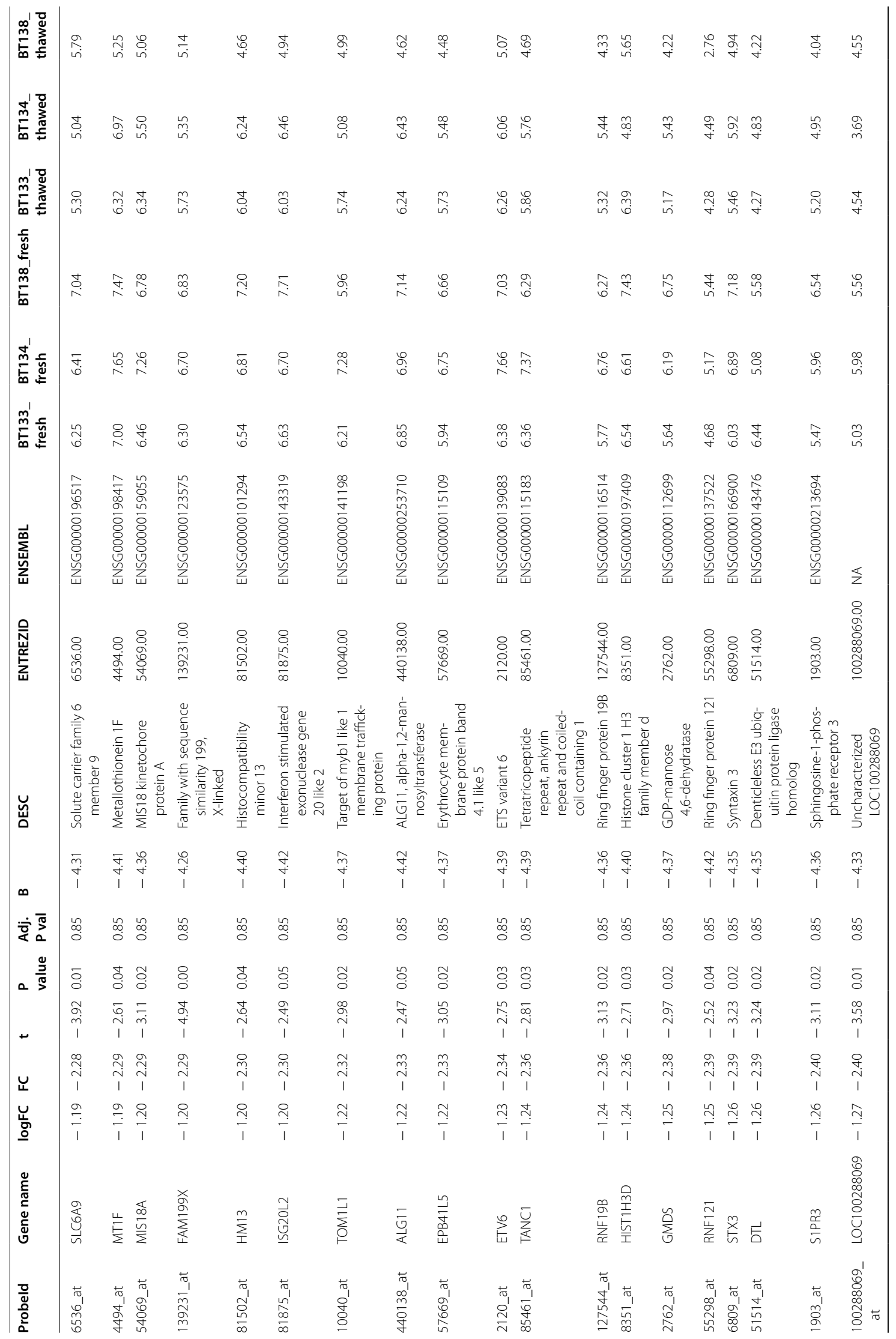




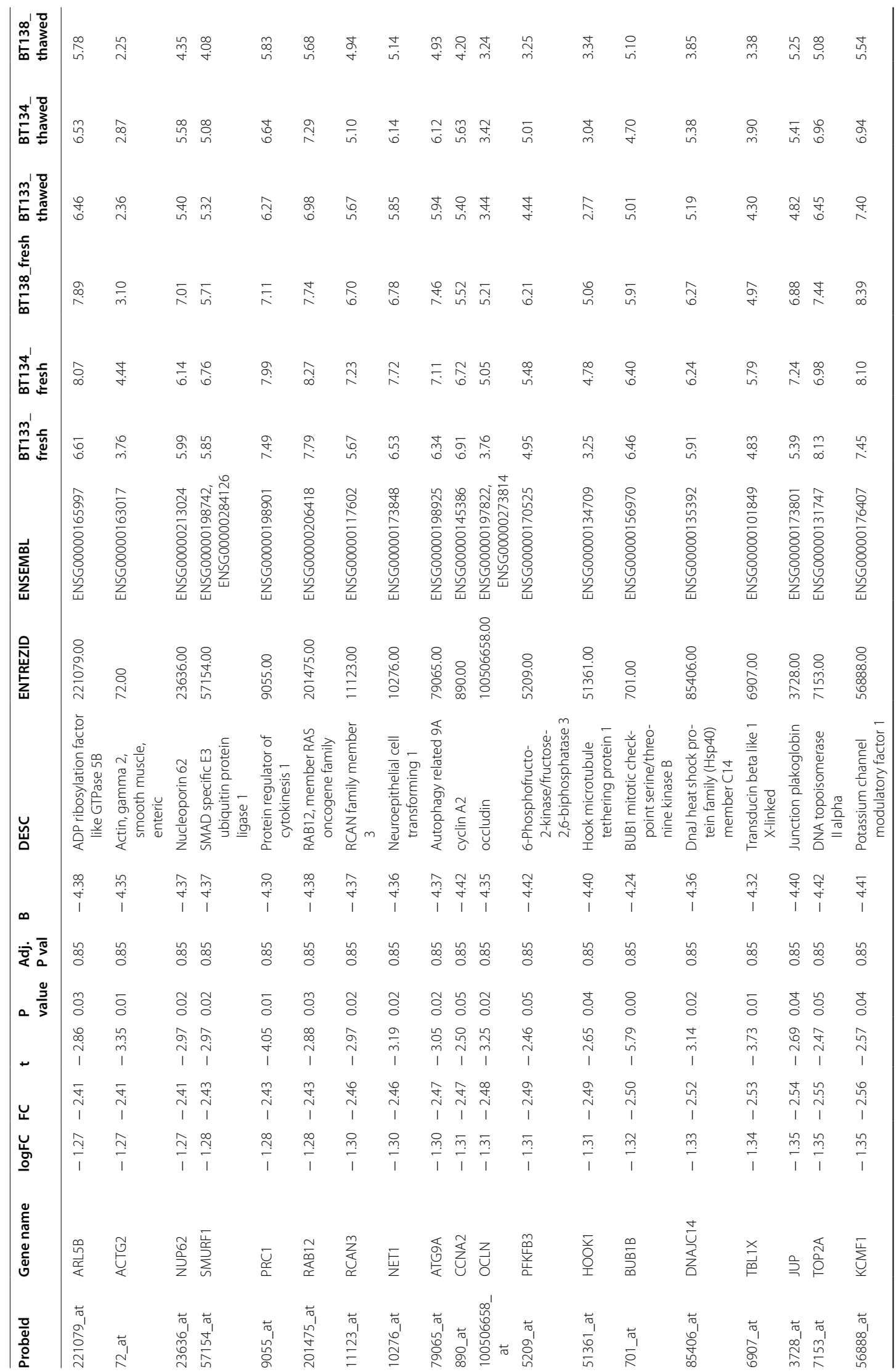




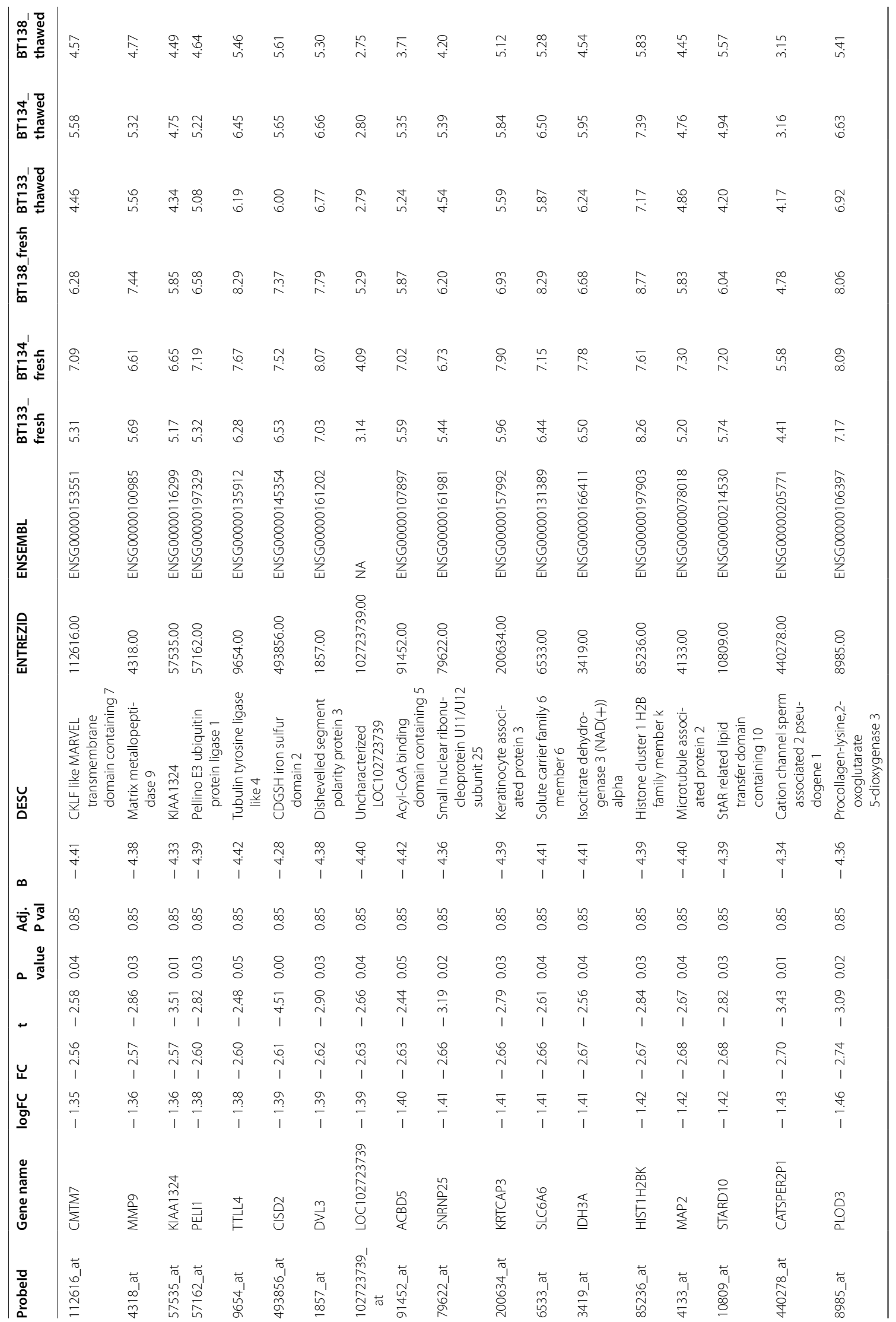




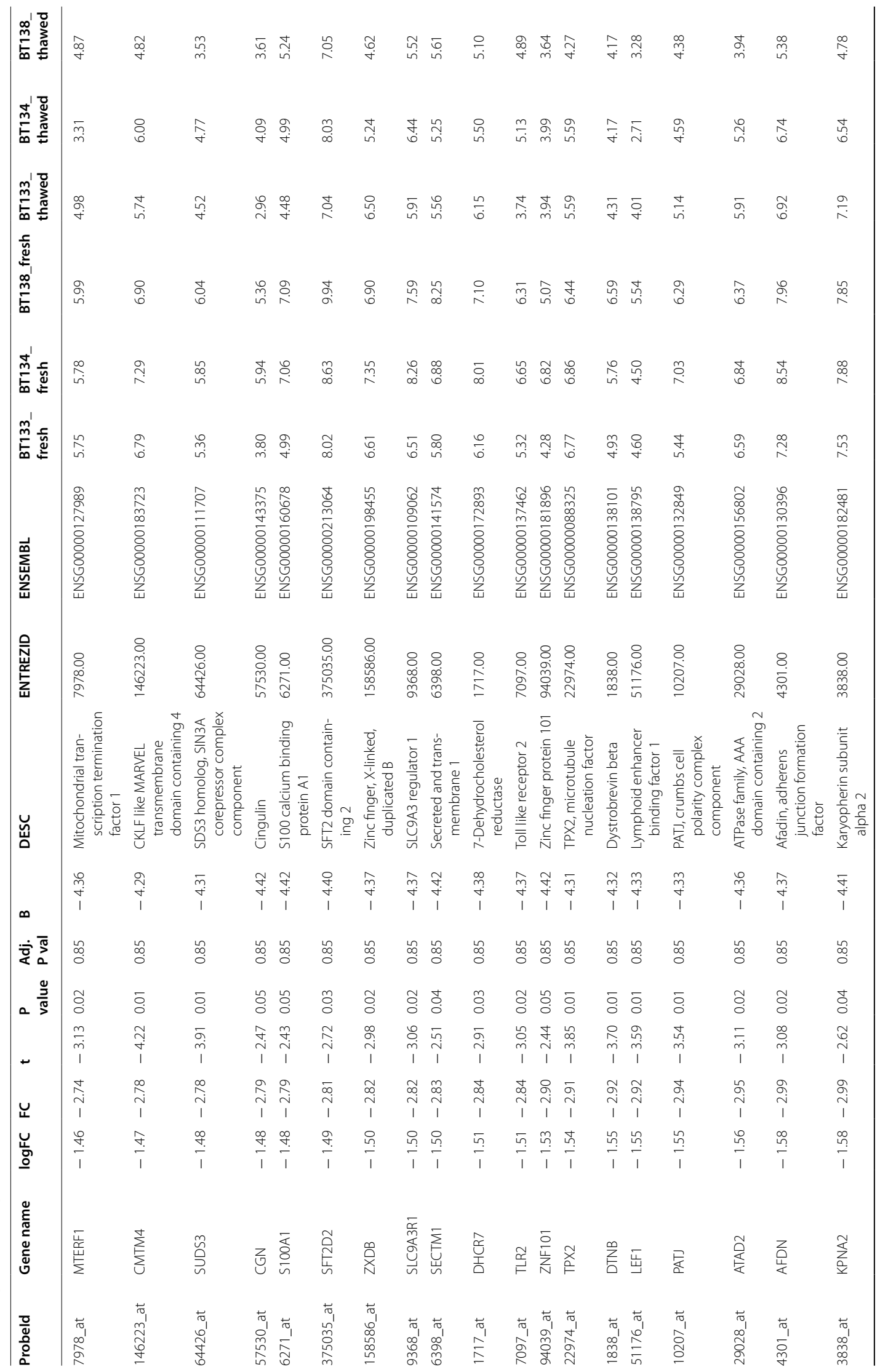


Le Gallo et al. BMC Res Notes (2018) 11:401

Page 16 of 20

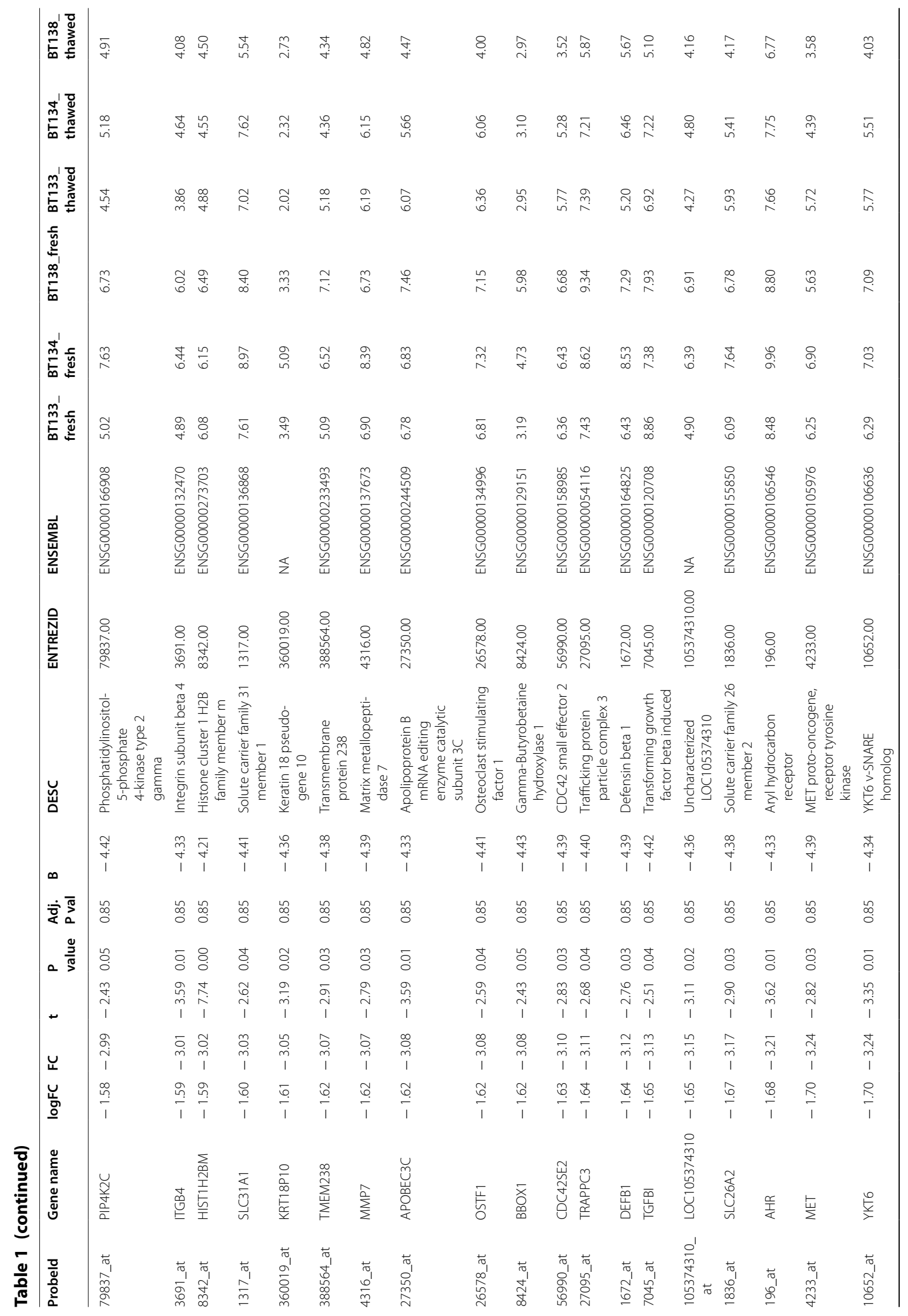




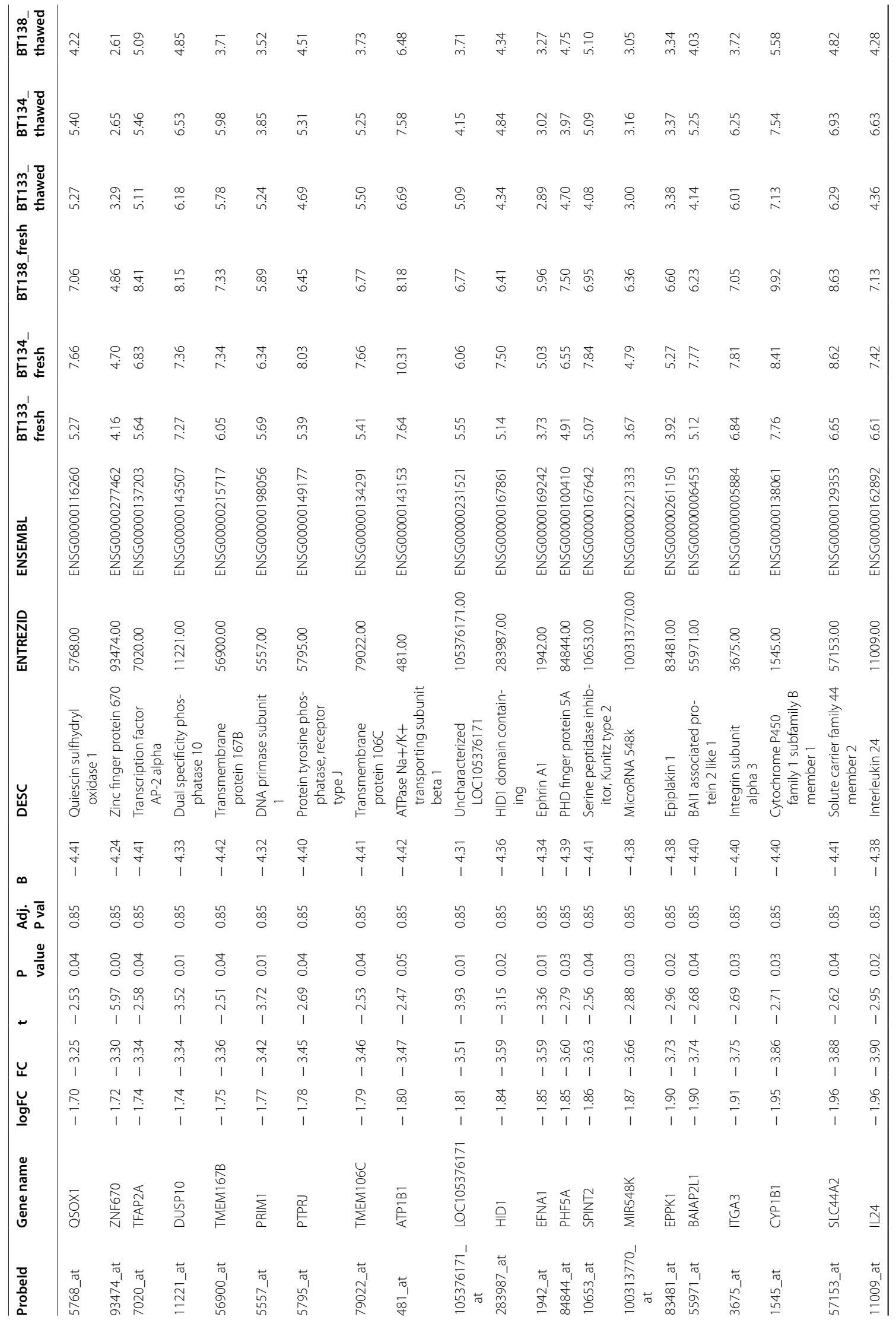




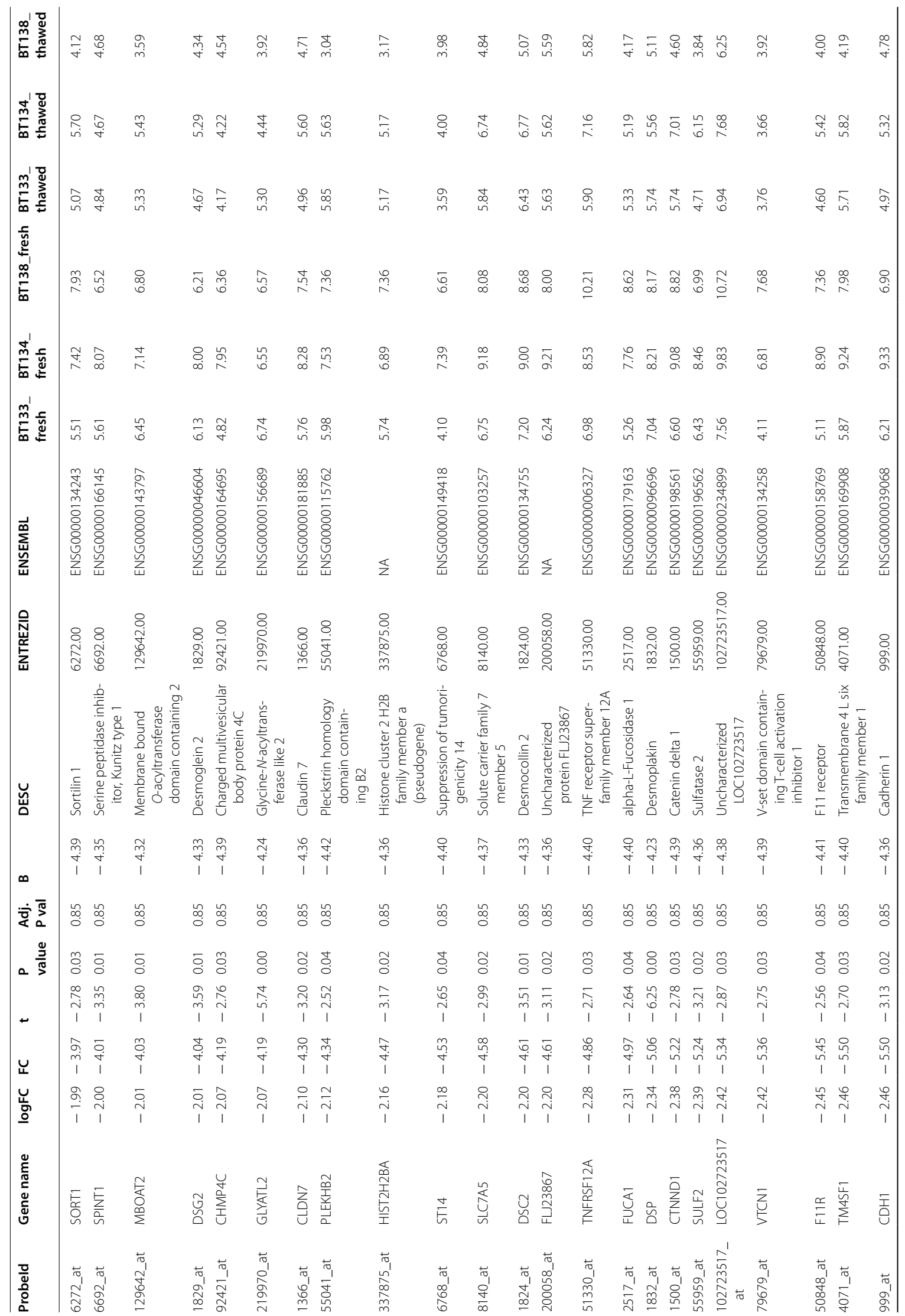




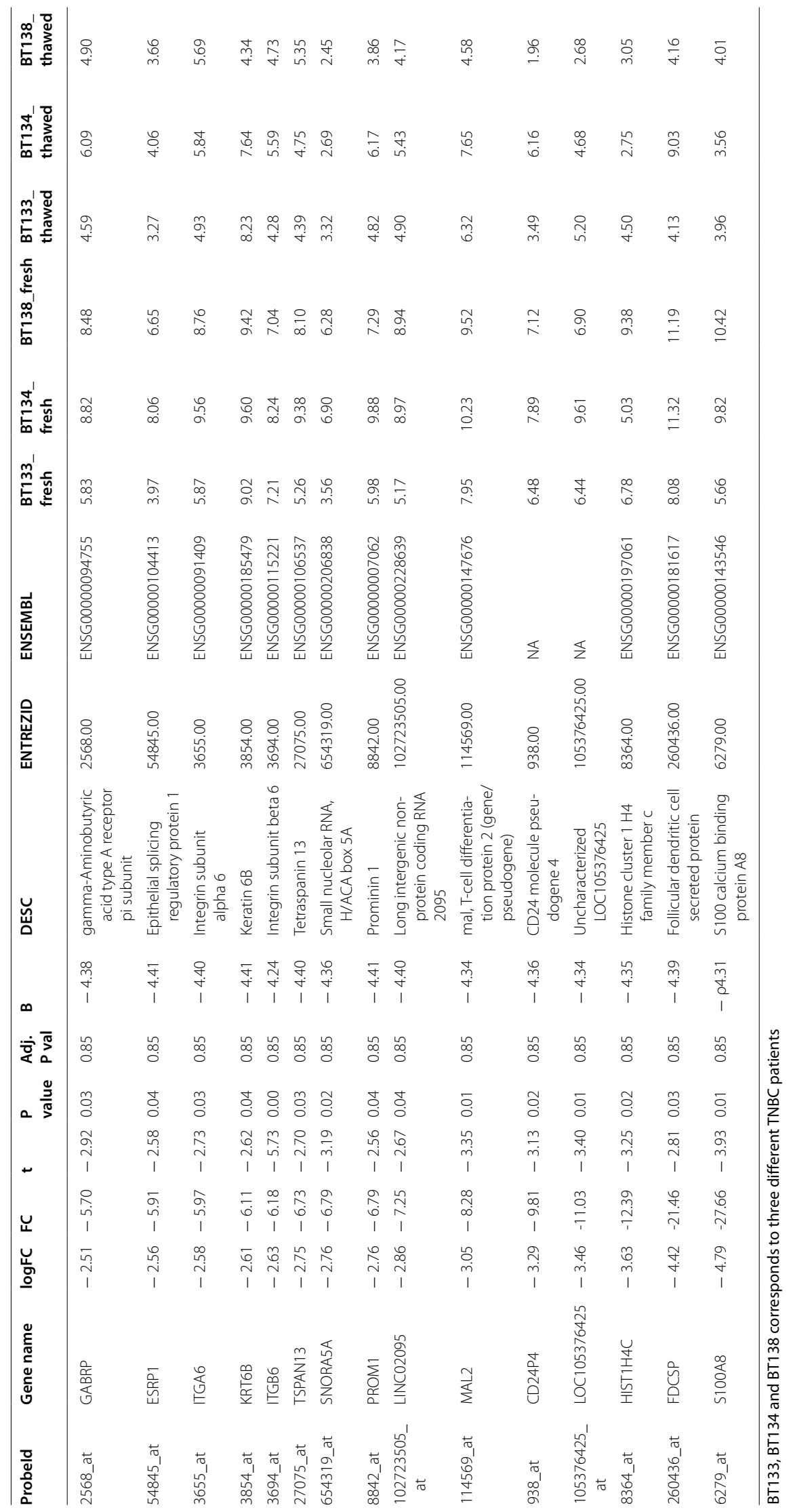




\section{Additional files}

Additional file 1: Figure S1. Flowchart showing the TNBC dissociation and spheroid protocols.

Additional file 2: Table S1. Gene ontology enrichment associated with the freeze/thaw process in TNBCs.

\section{Authors' contributions}

MLG, TMR and AP conducted the experiments and analyzed data. VL, PT, JL and FG provided tumor samples and analyzed data. MLG, TMR, VL, JL, FG and $P L$ wrote the paper. PL designed the experiments and supervised the project. All authors read and approved the final manuscript.

\section{Author details}

${ }^{1}$ COSS (Chemistry Oncogenesis Stress Signaling)-UMR 1242, Inserm, Univ Rennes, CLCC Eugène Marquis, Rue Bataille Flandres Dunkerque, 35042 Rennes, France. ${ }^{2}$ Equipe Labellisée Ligue Contre Le Cancer, Rue Bataille Flandres Dunkerque, 35042 Rennes, France. ${ }^{3}$ CHU Pontchaillou, Rennes, France. ${ }^{4}$ Present Address: Oregon Health and Science University, Portland, USA.

\section{Acknowledgements}

We are grateful to the CRB Rennes for its technical assistance.

This work was supported by INCa PLBIO, Ligue Contre le Cancer and Fondation ARC.

\section{Competing interests}

The authors declare that they have no competing interests.

\section{Availability of data and materials}

The study was conducted with human samples and clinical data of Rennes Biobank Breast Cancer Collection (BRIF Number: BB-0033-00056) certified NF 596900 for receipt preparation preservation and provision of biological resources. Raw and normalized transcriptomic data have been deposited to the GEO database accession ID GSE114359. All data generated or analyzed during this study are included in this published article.

\section{Consent for publication}

Not applicable.

\section{Ethics approval and consent to participate}

The breast Cancer Collection was declared and approved by the French institution since 2008 (DC-2008-338). All patients provided written informed consent to the use of surgical specimens and clinic-pathological data for research purposes [as required by the French Committee for the Protection of Human Subjects (CCPPRB)]. Rennes CCPPRB approved the use of tumor tissues for this study (6 May 2013: No. 357/2013). Collection of tumors was approved by French Minister of higher education and research (No. AC-2008-141). The study did not need additional ethical approval.

\section{Funding}

This work was supported by INCa PLBIO, Ligue Contre le Cancer and Foundation ARC. The funders had no role in study design, data collection and analysis, decision to publish, or preparation of the manuscript.

\section{Publisher's Note}

Springer Nature remains neutral with regard to jurisdictional claims in published maps and institutional affiliations.

Received: 11 May 2018 Accepted: 12 June 2018

Published online: 20 June 2018

\section{References}

1. Cronin KA, Lake AJ, Scott S, Sherman RL, Noone AM, Howlader N, Henley SJ, Anderson RN, Firth AU, Ma J, et al. Annual report to the nation on the status of cancer, part I: national cancer statistics. Cancer. 2018. https://doi. org/10.1002/cncr.31551.

2. Negoita S, Feuer EJ, Mariotto A, Cronin KA, Petkov VI, Hussey SK, Benard V, Henley SJ, Anderson RN, Fedewa S, et al. Annual report to the nation on the status of cancer, part II: recent changes in prostate cancer trends and disease characteristics. Cancer. 2018. https://doi.org/10.1002/cncr.31549.

3. Ali HR, Chlon L, Pharoah PD, Markowetz F, Caldas C. Patterns of immune infiltration in breast cancer and their clinical implications: a gene-expression-based retrospective study. PLoS Med. 2016;13:e1002194.

4. Oskarsson T, Batlle E, Massague J. Metastatic stem cells: sources, niches, and vital pathways. Cell Stem Cell. 2014;14:306-21.

5. Al-Hajj M, Wicha MS, Benito-Hernandez A, Morrison SJ, Clarke MF. Prospective identification of tumorigenic breast cancer cells. Proc Natl Acad Sci USA. 2003;100:3983-8.

6. Ginestier C, Hur MH, Charafe-Jauffret E, Monville F, Dutcher J, Brown M, Jacquemier J, Viens P, Kleer CG, Liu S, et al. ALDH1 is a marker of normal and malignant human mammary stem cells and a predictor of poor clinical outcome. Cell Stem Cell. 2007;1:555-67.

7. Gardner DK, Sheehan CB, Rienzi L, Katz-Jaffe M, Larman MG. Analysis of oocyte physiology to improve cryopreservation procedures. Theriogenology. 2007;67:64-72.

8. Bianchi F, Nicassio F, Di Fiore PP. Unbiased vs. biased approaches to the identification of cancer signatures: the case of lung cancer. Cell Cycle. 2008; 7:729-34.

\footnotetext{
Ready to submit your research? Choose BMC and benefit from:

- fast, convenient online submission

- thorough peer review by experienced researchers in your field

- rapid publication on acceptance

- support for research data, including large and complex data types

- gold Open Access which fosters wider collaboration and increased citations

- maximum visibility for your research: over $100 \mathrm{M}$ website views per year
}

At BMC, research is always in progress.

Learn more biomedcentral.com/submissions 